\title{
The Influence of Fungicide Treatment on the Production and the Quality of Several Autumn Wheat Varieties
}

\author{
Loredana SUCIU ${ }^{1,2}$, Raluca MICLEA ${ }^{1}$, Rozalia KADAR ${ }^{2}$, Carmen PUIA ${ }^{1 *}$ \\ ${ }^{1}$ University of Agricultural Sciences and Veterinary Medicine, Faculty of Agriculture, 3-5, Mănăştur, \\ ${ }^{2}$ Agricultural Research \& Development Station Turda, Agriculturii street, No.27, 401100, Turda, \\ Romania \\ * corresponding author: carmen.puia@yahoo.com
}

Bulletin USAMV series Agriculture 72(1)/2015

Print ISSN 1843-5246; Electronic ISSN 1843-5386

DOI 10.15835/buasvmcn-agr: 11173

\begin{abstract}
The wheat production range from one year to another and is influenced by the climatic conditions, the cultivated variety and the presence of the pathogens which cause foliar and ear diseases. Also the quality of production (protein and gluten) is influenced by the pedological and climatic condition and diseases. The effect of the fungicide treatments in vegetation on the production and quality was studied in 2012-2013 at ARDS Turda, in the Phytopathology laboratory field. The study was conducted with five wheat varieties: Ariesan, Apullum, Turda 2000, Dumbrava and Andrada and the test variants were: no treatment (T0), one treatment, (T1) and two treatments (T2). The vegetation treatments have been carried out with the products Nativo (11/ha) at the flag leaf appearance and Prosaro (1l/ha) at the end of the flowering. Since the Fusarium head blight, produced by different species of the genus Fusarium, is the most important disease in wheat crops and has a high impact on the quality and quantity of production, the percentage of diseased kernels was determined. The production was evaluated in $\mathrm{kg} / \mathrm{ha}$ and the qualitative parameters were determined using the INSTALAB600 and AGRI CECK analyzer. Following the observations made and the statistical interpretation of data, we can say that applying vegetation treatments the percentage of diseased grains decreases compared to the control. The yield increases when treatment was applied. The gluten and the protein content recorded a slight decrease or increase, depending on the test variant; the ash content decreased when the treatments were applied on the vegetation period. The application of fungicide treatment on the vegetation is an important link in the wheat cultivation technology, ensuring the achievement quantitative and qualitative higher production.
\end{abstract}

Keywords: fungicide, quality, yield, wheat

\section{INTRODUCTION}

The winter wheat crops are affected by many diseases that cause significant quantitative and qualitative damages, damaging the food, feed and seed culture.

Wheat production varies from year to year, influenced by the climatic conditions, the variety grown and the presence of pathogens causing foliar and ear diseases. Production quality (protein and gluten) is influenced by the pedological environment, climatic conditions but also by the diseases.

From the many diseases present in wheat culture, Fusarium ear blight, is responsible for reducing the production of wheat and also contributes to it is decrease.

Along with the seed treatment, fungicide treatments on vegetation helps to control pathogens like Fusarium spp., with the condition 
that fungicides are applied in the BBCH 61- BBCH 65 stage.

\section{MATERIALS AND METHODS}

The study of fungicide treatments in vegetation on the quantity and quality of winter wheat production was achieved in 2012-2013 at ARDS Turda, in the Phytopathology laboratory. As biological material there have been used five wheat varieties: Ariesan, Apullum Turda 2000, Dumbrava and Andrada. Test variants were: no treatment (T0), a treatment (T1), and two treatments (T2) (Tab. 1). Treatments were carried out on Nativo (1 l / ha), (pebuconazol $200 \mathrm{~g} / \mathrm{l}+$ trifloxystrobin $100 \mathrm{~g} / \mathrm{l}$ ) at the flag leaf emergence and Prosaro (1 l / ha) (prothioconazole $125 \mathrm{~g} / \mathrm{l}+$ tebuconazole $125 \mathrm{~g} / \mathrm{l}$ ) (Hershman and Johnson, 2009 Welugo and Klein, 2013), at the end of flowering. Since Fusarium head blight produced by different species of the Fusarium genus, is the most important disease in wheat crop with a major impact on the quality and quantity of production, it was determined the percentage of diseased kernels (\%). Production was measured in $\mathrm{kg} / \mathrm{ha}$. The quality parameters were determined using INSTALAB 600 and AGRI CHEK analyzer. Data obtained from the observation were processed using POLIFACT.

\section{RESULTS AND DISCUSSIONS}

The climatic conditions influence of the growing and developing of plants but also the emergence and evolution of pathogens. The year 2012, due to the temperatures recorded was a very warm year. The lack of water in the soil, combined with the lack of rainfall in late 2011 led to the emergence of wheat only in the spring of 2012.
Tab. 1. List of the field plot variants

\begin{tabular}{cc}
\hline Variant signification & Treatment \\
\hline T0 & $\begin{array}{c}\text { control variant with seed } \\
\text { treatment }\end{array}$ \\
\hline T1 & $\begin{array}{c}\text { seed treatment and one } \\
\text { vegetation treatment }\end{array}$ \\
T2 & $\begin{array}{c}\text { seed treatment and two } \\
\text { vegetation treatments }\end{array}$ \\
\hline
\end{tabular}

(Source: The meteorological station Turda (longitudinal: 23 47'; latitudinal 46³5'; altitudinal $427 \mathrm{~m}$ )

Even though the year 2012 was not normal in terms of climatic conditions, the varieties studied behaved well, being stable in terms of production and high capacity to adapt to different environmental conditions. In terms of temperatures, the year 2013 was a hot year, with temperatures that were slightly above the average of 55 years (Fig. 1).

(Source: The meteorological station Turda (longitudinal: 23 ${ }^{\circ}$ 47'; latitudinal 46 $35^{\prime}$; altitudinal $427 \mathrm{~m}$ )

The years 2012 and 2013 are characterized as normal in terms of rainfall. Rainfall in April, May and June (Fig. 2) in the two experimental years, have influenced the emergence and development of the pathogens.

In order to determine the influence of the vegetation treatments on the quantity and quality production of winter wheat varieties the percentage of diseased kernels was determined for the varieties studied in the two years of experimentation.

The climatic conditions of the two experimental years of experimentation have

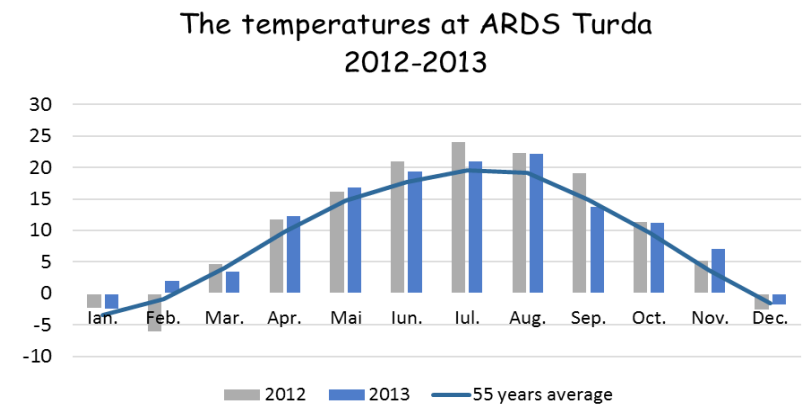

Fig. 1. The temperatures at ARDS Turda 2012-2013

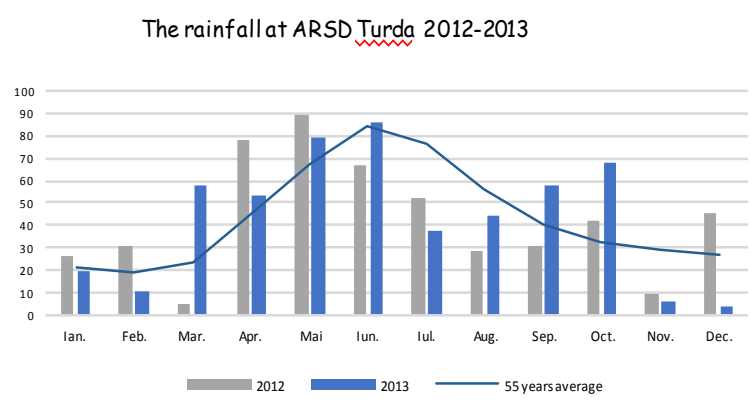

Fig. 2. The rainfall regime at ARDS Turda 2012-2013 
influenced the emergence and the manifestation of the diseases. In 2013, the average percentage of diseased kernels in all varieties studied in all experimental variants was higher, with a positive significant difference compared to the control (Tab. 2).

Regarding the influence of the number of vegetation treatments on the percentage of the diseased kernels we can say that by applying one or two treatments the percentage of attacked kernels was lower regardless of the number of treatments, recording negative significant differences compared to the control, on which no treatment was applied (Tab. 3).
Between the averages percentage of diseased kernels of all the variants, there were differences, but they were not statistically assured (Tab. 3). However we notice that the variety Dumbrava recorded the lowest percentage of diseased kernels $(15.78 \%)$ and the variety Appulum, recorded the highest percentage of kernels attacked by Fusarium spp. (19.51\%).

The application of the fungicide treatments on vegetation, contributes alongside with the agrotechnical measures (crop rotation, sowing period, balanced fertilization, cultivation of resistant varieties) at the obtaining of high yields.

Tab. 2. The influence of the climatic condition on the diseased kernels $2012-2013$

\begin{tabular}{lccccc}
\hline No. & Year & $\begin{array}{c}\text { Diseased kernels } \\
\%\end{array}$ & $\begin{array}{c}\% \text { to } \\
\text { control }\end{array}$ & $\begin{array}{c}\text { The difference } \\
\text { to control }\end{array}$ & $\begin{array}{c}\text { The significance } \\
\text { of the difference }\end{array}$ \\
\hline 1. & 2012 & 12.69 & 100.0 & 0.00 & Control \\
\hline 2. & 2013 & 22.93 & 180.7 & 10.24 & $*$ \\
\hline LDS (p 5\%) & \multicolumn{5}{c}{6.01} \\
LDS(p 1\%) & \multicolumn{5}{c}{13.88} \\
LDS (p 0.1\%) & & 44.18
\end{tabular}

Tab. 3. The influence of the number of treatments on the diseased kernels 2012 2013

\begin{tabular}{lccccc}
\hline No. & $\begin{array}{c}\text { Number of } \\
\text { treatments }\end{array}$ & $\begin{array}{c}\text { Diseased } \\
\text { kernels } \%\end{array}$ & $\begin{array}{c}\% \text { to } \\
\text { control }\end{array}$ & $\begin{array}{c}\text { The difference } \\
\text { to control }\end{array}$ & $\begin{array}{c}\text { The significance } \\
\text { of the difference }\end{array}$ \\
\hline 1. & T0 & 24.86 & 100.0 & 0.00 & Control \\
\hline 2. & T1 & 17.32 & 69.7 & -7.54 & 000 \\
\hline 3. & T2 & 11.25 & 45.3 & -13.61 & 000 \\
\hline LDS (p 5\%) & & 1.95 & & \\
LDS (p 1\%) & & 2.60 & & \\
LDS (p 0.1\%) & & 3.42 & &
\end{tabular}

Tab. 4 The behavior of the five varieties on Fusarium spp., attack 2012 - 2013

\begin{tabular}{lccccc}
\hline No. & Varieties & $\begin{array}{c}\text { Diseased } \\
\text { kernels } \%\end{array}$ & $\begin{array}{c}\% \text { to } \\
\text { control }\end{array}$ & $\begin{array}{c}\text { The difference } \\
\text { to control }\end{array}$ & $\begin{array}{c}\text { The significance of } \\
\text { the difference }\end{array}$ \\
\hline 1. & ARIESAN & 17.88 & 100.0 & 0.00 & Control \\
\hline 2. & APULLUM & 19.51 & 109.1 & 1.62 & - \\
\hline 3. & TURDA 2000 & 17.31 & 96.8 & -0.57 & - \\
\hline 4. & DUMBRAVA & 15.78 & 88.2 & -2.11 & - \\
\hline $5 . \quad$ ANDRADA & 18.58 & 103.9 & 0.70 & - \\
\hline LDS(p 5\%) & & 3.01 & & \\
LDS (p 1\%) & & 4.14 & & \\
LDS (p 0.1\%) & & 5.71 & &
\end{tabular}


In the experimental conditions of the ARDS Turda, applying the vegetation treatments have lead to the increasing of the production with yields between 414 and $1404 \mathrm{~kg}$ / ha in 2012 (Tab 4). In 2013, the yields were slightly lower, with the exception of the Andrada and Dumbrava varieties, production increased ranging from 21 to 1119 $\mathrm{kg} / \mathrm{ha}$, aspect that was correlated with higher percentage of sick kernels this year.
In the two years of experiments, Dumbrava variety has achieved the highest yields. In year 2012, the differences of production compared to the control were statistically assured. In 2013 the application of two treatments on vegetation leads to a higher production, with the positive significant difference to the control (Tab. 5).

Yield increases were registered at the Appulum and Turda 2000 varieties, in 2012, by applying

Tab. 5. The influence of the climatic conditions and the number of treatments on the production

\begin{tabular}{|c|c|c|c|c|c|c|c|}
\hline No. & Year & Cultivars & $\begin{array}{l}\text { Number of } \\
\text { treatments }\end{array}$ & $\begin{array}{l}\text { Yield } \\
\mathrm{kg} / \mathrm{ha}\end{array}$ & $\begin{array}{l}\% \text { to } \\
\text { control }\end{array}$ & $\begin{array}{l}\text { The difference } \\
\text { to control }\end{array}$ & $\begin{array}{l}\text { The significance } \\
\text { of the difference }\end{array}$ \\
\hline 1. & \multirow{15}{*}{2012} & \multirow{3}{*}{ ARIESAN } & T0 & 7816 & 100.0 & 0.00 & Control \\
\hline 2. & & & $\mathrm{~T} 1$ & 8264 & 105.7 & 448 & - \\
\hline 3. & & & $\mathrm{~T} 2$ & 8339 & 106.7 & 523 & - \\
\hline 4. & & \multirow{3}{*}{ APULLUM } & T0 & 7002 & 100.0 & 0.00 & Control \\
\hline 5. & & & $\mathrm{~T} 1$ & 7517 & 107.4 & 516 & - \\
\hline 6. & & & $\mathrm{~T} 2$ & 8243 & 117.7 & 1241 & $* *$ \\
\hline 7. & & \multirow{3}{*}{ TURDA 2000} & T0 & 7309 & 100.0 & 0.00 & Control \\
\hline 8. & & & $\mathrm{~T} 1$ & 8063 & 110.3 & 754 & - \\
\hline 9. & & & $\mathrm{~T} 2$ & 8313 & 113.7 & 1004 & * \\
\hline 10. & & \multirow{3}{*}{ DUMBRAVA } & T0 & 7487 & 100.0 & 0.00 & Control \\
\hline 11. & & & $\mathrm{~T} 1$ & 8777 & 117.2 & 1290 & $* *$ \\
\hline 12. & & & $\mathrm{~T} 2$ & 8891 & 118.8 & 1404 & $* * *$ \\
\hline 13. & & \multirow{3}{*}{ ANDRADA } & T0 & 7677 & 100.0 & 0.00 & Control \\
\hline 14. & & & $\mathrm{~T} 1$ & 8091 & 105.4 & 414 & - \\
\hline 15. & & & $\mathrm{~T} 2$ & 8342 & 108.7 & 665 & - \\
\hline 16. & \multirow{15}{*}{2013} & \multirow{3}{*}{ ARIESAN } & T0 & 7830 & 100.0 & 0.00 & Control \\
\hline 17. & & & $\mathrm{~T} 1$ & 7851 & 100.3 & 21 & - \\
\hline 18. & & & $\mathrm{~T} 2$ & 7936 & 101.4 & 106 & - \\
\hline 19. & & \multirow{3}{*}{ APULLUM } & T0 & 7427 & 100.0 & 0.00 & Control \\
\hline 20. & & & $\mathrm{~T} 1$ & 7582 & 102.1 & 155 & - \\
\hline 21. & & & $\mathrm{~T} 2$ & 7656 & 103.1 & 229 & - \\
\hline 22. & & \multirow{3}{*}{ TURDA 2000} & T0 & 7560 & 100.0 & 0.00 & Control \\
\hline 23. & & & $\mathrm{~T} 1$ & 7614 & 100.7 & 54 & - \\
\hline 24. & & & $\mathrm{~T} 2$ & 7754 & 102.6 & 194 & - \\
\hline 25. & & \multirow{3}{*}{ DUMBRAVA } & T0 & 7985 & 100.0 & 0.00 & Control \\
\hline 26. & & & $\mathrm{~T} 1$ & 8447 & 105.8 & 462 & - \\
\hline 27. & & & $\mathrm{~T} 2$ & 9184 & 115.0 & 1199 & $* *$ \\
\hline 28. & & \multirow{3}{*}{ ANDRADA } & T0 & 7666 & 100.0 & 0.00 & Control. \\
\hline 29. & & & $\mathrm{~T} 1$ & 8512 & 111.0 & 846 & $*$ \\
\hline 30. & & & $\mathrm{~T} 2$ & 8626 & 112.5 & 960 & $*$ \\
\hline LDS (p & & & & 802.2 & & & \\
\hline LDS (p & $1 \%$ ) & & & 1072. & & & \\
\hline
\end{tabular}


two treatments on vegetation, and in 2013 the Andrada variety yields was higher in variants with one and two vegetation treatments, the difference compared with control being significantly positive (Tab. 5).

As regards its quality - protein, gluten and ash - they can be influenced by the infection with Fusarium spp.

The protein content can increase, decrease or remain constant at the Fusarium attack. Boyacioğlu and Hettiarachchy in 1995 have seen an increase in protein content after infection with Fusarium spp. Other authors (Dexter et al. in 1997, Gartner et al., in 2008), have observed a slight decrease in the protein content and Marie Kreuzberger, in 2011, stated that the Fusarium infections did not affect the protein content. The environmental conditions (year x location) the preceding crop and the cultivar type might influence the protein content.

Following the analyzes of the wheat samples from those five wheat varieties, it can be seen that

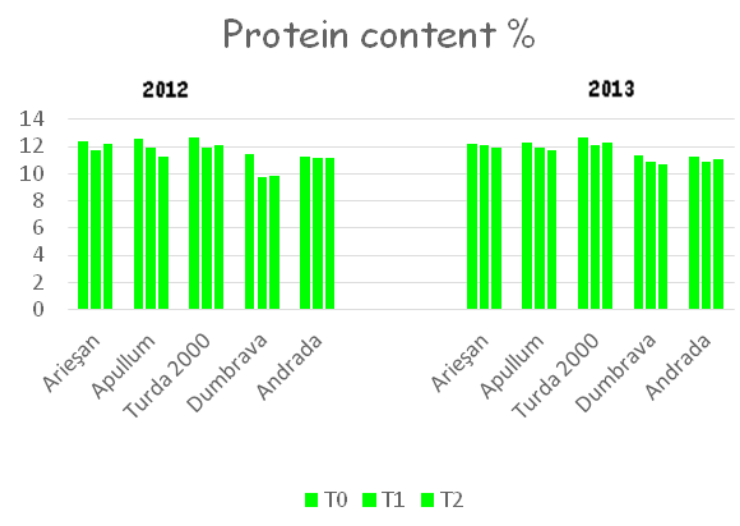

Fig. 3. The protein content in 2012-2013

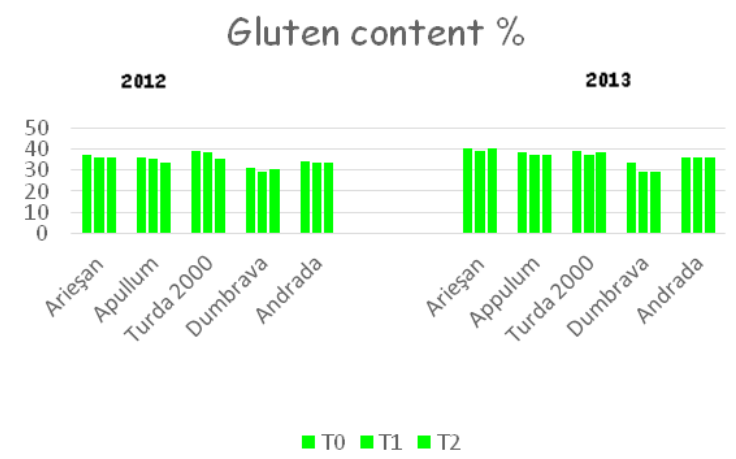

Fig. 4. The gluten content in 2012-2013 in the variant where no treatments were applied, the protein content is higher in both experimental years, correlated with the reduced production from all varieties, in this version, but with a high percentage of attacked kernels. The application of treatment leads to a slight decrease in the protein content in the single-treatment variant and increased slightly after the application of the second treatment, the protein content did not exceed the untreated variant (Fig. 3).

Due to the positive correlation that exists between protein and gluten content in our samples we could noticed that in the case of the variant without treatments, in all varieties taken under study, in both experimental years, the amount of gluten is higher. It was observed a slight decrease or even the same values when applying the vegetation treatments (Fig. 4).

The ash content in the flour obtained from infected grains with Fusarium, increase as was studied by Marie Kreuzberger, 2011). Ludmila Papoušková et al (2011) also noted an increase in ash content in the flour obtained from wheat infected with Fusarium.

The ash content is higher in the variant without vegetation treatment correlated with a higher percentage of diseased kernels. The application of vegetation treatments leads to the decreasing of the ash content in flour obtained from the studied varieties (Fig. 5).

To highlight the influence of the fungicide vegetation treatments on the quantity and quality of production, we have calculated the average yields per hectare in the two experimental years and the average amount of protein per hectare for all the varieties.

It can be seen in Tab. 6 that the highest amount of protein per hectare was obtained in

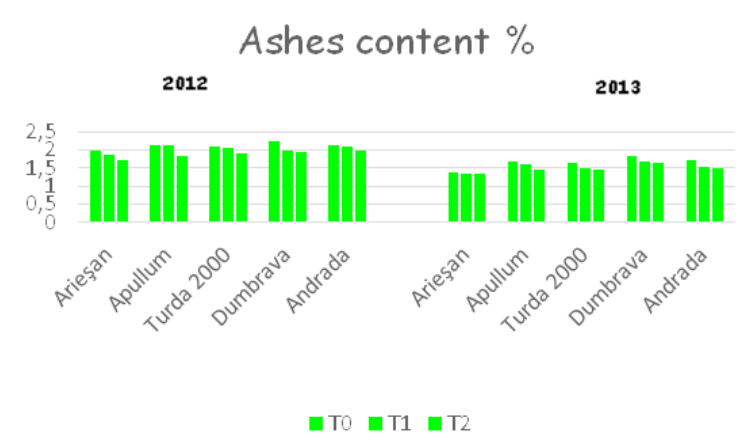

Fig. 5. The ashes content in 2012-2013 
Tab 6. The protein content (kg/ha) in 2012-2013

\begin{tabular}{|c|c|c|c|c|c|}
\hline No. & Cultivars & $\begin{array}{l}\text { Number of } \\
\text { treatments }\end{array}$ & $\begin{array}{c}\text { Yield average } \\
\text { 2012-2013 } \\
\text { (kg/ha) }\end{array}$ & $\begin{array}{l}\text { Protein average } \\
\text { content } \\
2012-2013(\%)\end{array}$ & $\begin{array}{c}\text { Protein average } \\
\text { content } \\
(\mathrm{kg} / \mathrm{ha})\end{array}$ \\
\hline 1. & \multirow{3}{*}{ ARIESAN } & T0 & 7823 & 12.2 & 962 \\
\hline 2. & & $\mathrm{~T} 1$ & 8056 & 11.9 & 959 \\
\hline 3. & & $\mathrm{~T} 2$ & 8138 & 12.1 & 981 \\
\hline 4. & \multirow{3}{*}{ APULLUM } & T0 & 7215 & 12.5 & 898 \\
\hline 5. & & $\mathrm{~T} 1$ & 7550 & 11.9 & 899 \\
\hline 6. & & $\mathrm{~T} 2$ & 7950 & 11.9 & 946 \\
\hline 7. & \multirow{3}{*}{ TURDA 2000} & T0 & 7435 & 12.7 & 944 \\
\hline 8. & & $\mathrm{~T} 1$ & 7839 & 12.0 & 941 \\
\hline 9. & & $\mathrm{~T} 2$ & 8034 & 12.2 & 980 \\
\hline 10. & \multirow{3}{*}{ DUMBRAVA } & T0 & 7736 & 11.3 & 874 \\
\hline 11. & & $\mathrm{~T} 1$ & 8612 & 10.4 & 891 \\
\hline 12. & & $\mathrm{~T} 2$ & 9037 & 10.3 & 931 \\
\hline 13. & \multirow{3}{*}{ ANDRADA } & T0 & 7667 & 11.3 & 867 \\
\hline 14. & & $\mathrm{~T} 1$ & 8301 & 11.1 & 921 \\
\hline 15. & & $\mathrm{~T} 2$ & 8484 & 11.2 & 950 \\
\hline
\end{tabular}

the variant where applied two treatments in vegetation, although in this variant the protein content was slightly lower than in the untreated variant. In some varieties (Ariesan and Turda 2000) the variant without vegetation treatments have achieved high amounts of protein, but it should be noted that in this variant the percentage of the kernels damaged by Fusarium spp. was the highest, aspect that leads to higher ash content and a lower quality of flour.

\section{CONCLUSION}

The climatic conditions influenced the percentage of attacked kernels by Fusarium spp., in 2013 the percentage of diseased kernels was higher in all studied varieties, compared to 2012;

The number of vegetation treatments influenced the percentage of diseased kernels; by applying a single treatment or two treatments on vegetation the percentage of diseased kernels decreased very significantly compared with the untreated control variant;

In the experimental conditions from the ARDS Turda, applying of vegetation treatments has leaded to increased yields between 21 and $1404 \mathrm{~kg}$ / ha, depending on the number of treated, applied;

The application of vegetation treatments leads to a slight decrease in the protein percentage in a single treatment variant and to a slight increase after the application of two treatments, values that did not exceed the protein content recorded in the untreated control;

In case of applying vegetation treatments the amount of gluten recorded a slight decrease compared to the amount of gluten obtained from the control;

The ash content was higher in the variant without vegetation treatment correlated with a higher percentage of diseased kernels; the application of treatments in vegetation decreased the ash content;

The highest amount of protein per hectare was obtained in the variant where two treatments were applied on vegetation and it can be said that the application of the two treatments on vegetation contributes to a higher production in terms of quantity and quality.

Acknowledgment: This paper was done through the Partnerships in priority areas - PN II program, developed with the MEN - UEFISCDI support, project no. PN-II-PT-PCCA-3013-4-1857. 


\section{REFERENCES}

1. Boyacioglu D, Hettiarachchy NS (1995). Changes in biochemical components of wheat infected with Fusarium graminearum. Journal of Cereal Science 21(1):57-62

2. Dexter JE, Marchylo BA, Clear R.M, Clarke JM (1997) Effect of Fusarium head blight on semolina millingand pasta-making quality of durum wheat. Cereal Chemistry 74:519-525.

3. Hershman DE, Johnson D (2009). Comprehensive Guide to Wheat Management in Kentucky, Disease Management, University of Kentucky. College of Agriculture, Food and Enviroment;
4. Kreuzberger M (2011). Fusarium infection of bread wheat and subsequent mycotoxin contamination of milling products: Impact on quality parameters and composition of flour, Doctoral Dissertation, Göttingen.

5. Papoušková LI, Capouchová M, Kostelanská A, Škeříková E, Prokinová J, Hajšlová J, Salava1and OF (2011). Changes in baking quality of winter wheat with differentintensity of fusarium spp. contamination detected by means of new rheological system mixolab. Czech J. Food Sci 29(4):420429.

6. Welugo SN, Klein RN (2013). Management of residue borne diseases of winter wheat, University of Nebraska - Lincon Extension, Institute of Agriculture and Natural Resources. 